Jurnal

Kardiologi Indonesia

J Kardiol Indones. 2015;36:38-45

ISSN 0I26/3773

\title{
Trimetazidine Effects on Neutrophils Count in Patients Post PPCI
}

\author{
Taka Mehi, Yoga Yuniadi, Nur Haryono
}

Departemen Kardiologi dan Kedokteran Vaskular Fakultas Kedokteran Universitas Indonesia, Pusat Jantung Nasional Harapan Kita
The incidence rate of ST-Elevation acute Myocardial Infarct (STEMI) keeps increasing. Currently, myocardial reperfusion, either with thrombolytic or Primary Percutaneous Coronary Intervention (PPCl), is the main treatment. However, mortality rate of STEMI patients undergoing PPCl is still high which is $6 \%$ to $14 \%$. The main purpose of $\mathrm{PPCl}$ is to restore the patency of infarcted epicardial artery and to establish microvascular reperfusion as soon as possible so that it can reduce enlargement of irreversible necrotic myocardial tissue. In the other hand, restored patency of infarcted epicardial artery does not indicate sufficient reperfusion to microvascular. Such phenomenon is called no-reflow or microvascular obstruction (MVO). Specific pathogenic component of MVO is reperfusion injury. Reperfusion injury involves some mediator and mechanisms, one of which is the process of thrombolysis and angioplasty. Mediator that play a certain role is inflammatory neutrophil which is activated and accumulated. Trimetazidine is an anti-ischemic agent which selectively inhibits end stage activation of oxidation pathway of 3-ketoacyl coenzyme Athiolase. Trimetazidine has an ability to reduce the accumulation of neutrophil.

(J Kardiol Indones. 20I5;36:38-45)

Keywords : Trimetazidine, microvascular obstruction, reperfusion injury 


\title{
Peranan Trimetazidine pada Reperfusion Injury
}

\author{
Taka Mehi
}

\begin{abstract}
Angka kejadian IMA EST semakin meningkat, reperfusi miokardium dengan trombolitik atau intervensi koroner perkutan primer ( IKPP) adalah terapi utama pada pasien yang mengalami IMA EST. Namun angka kematian saat di rumah sakit pada kelompok pasien dengan IKPP masih cukup bermakna yaitu 6\% hingga 14\%. Tujuan utama IKPP untuk mengembalikan patensi arteri epikardial yang mengalami infark dan mencapai reperfusi mikrovaskular secepat mungkin, sehingga dapat mengurangi perluasan trauma ireversibel atau nekrosis miokardium. Namun keberhasilan mengembalikan patensi dari arteri koroner epikardial setelah oklusi tidak selalu menjamin cukupnya reperfusi ke level mikrovaskular. Fenomena ini disebut noreflow atau microvascular obstruction (MVO). Salah satu komponen patogenetik dari MVO adalah reperfusion injury. Reperfusi aliran koroner diperlukan pada miokardium yang mengalami iskemia. Reperfusi memfasilitasi penyelamatan kardiomiosit dan menurunkan angka kesakitan dan kematian. Namun kebalikannya reperfusi area yang mengalami iskemia dapat menimbulkan disfungsi, yang disebut sebagai repefusion injury. Terjadinya reperfusion injury melibatkan beberapa mekanisme dan mediator, antara lain proses trombolisis dan angioplasty. Salah satu mediator yang berperan yaitu aktivasi dan akumulasi mediator inflamasi netrofil. Trimetazidine (TMZ;1-[2,3,4-trimethoxybenzyl]piperazine) adalah agen anti iskemia yang secara selektif menghambat aktivitas akhir dari enzim jalur oksidasi asam lemak 3-ketoacyl coenzyme Athiolase. Trimetazidine memiliki kemampuan menurunkan akumulasi netrofil.
\end{abstract}

(J Kardiol Indones. 2015;36:38-45)

Kata kunci: Trimetazidine, microvascular obstruction, reperfusion injury

\section{Latar belakang}

A ngka perawatan di rumah sakit karena infark miokardium akut dengan elevasi segmen ST (IMA EST) bervariasi pada berbagai negara. Salah satu contoh registry IMA EST yang paling komprehensif berasal dari Swedia, dimana insidensi nya sekitar 66/100.000/tahun. ${ }^{1}$

\footnotetext{
Alamat Korespondensi

dr. Taka Mehi, Dr. dr. Yoga Yuniadi, SpJP. , Departemen Kardiologi dan Kedokteran Vaskular Fakultas Kedokteran Universitas Indonesia, Pusat Jantung Nasional Harapan Kita. E-mail: taka_mehi@ yahoo.com
}

Pada masa sekarang, reperfusi miokardium dengan trombolitik atau intervensi koroner perkutan primer ( IKPP) adalah terapi utama pada pasien yang mengalami IMA EST. Namun berdasarkan data dari Second Euro Heart Survey 2004 angka kematian saat di rumah sakit pada kelompok pasien dengan IKPP masih cukup bermakna yaitu 6\% hingga 14\%. ${ }^{2}$

Tujuan utama IKPP untuk mengembalikan patensi arteri epikardial yang mengalami infark dan mencapai reperfusi mikrovaskular secepat mungkin, sehingga dapat mengurangi perluasan trauma ireversibel atau nekrosis miokardium. ${ }^{3}$ Namun keberhasilan mengembalikan patensi dari arteri koroner epikardial setelah oklusi tidak selalu menjamin cukupnya reperfusi ke level mikrovaskular. Fenomena ini disebut 
no-reflow atau microvascular obstruction (MVO).,5 No reflow berhubungan dengan prognosis yang buruk, remodeling ventrikel kiri, gagal jantung dan meningkatkan risiko aritmia dan kematian. ${ }^{5}$ Oleh karena itu sangat penting untuk mengidentifikasi dan mencegah fenomena ini.

\section{I Mekanisme MVO}

Konsep no reflow merujuk pada suatu kondisi hipoperfusi jaringan miokardium meskipun arteri koroner epikardium sudah paten. ${ }^{6}$ Terdapat 4 komponen patogenetik pada fenomena no reflow yaitu: embolisasi aterotrombotik distal, trauma iskemia, trauma reperfusi dan kecenderungan mikrosirkulasi koroner mengalami trauma, seperti yang dapat dilihat pada gambar $1 .^{3}$ Pada makalah ini pembahasan akan difokuskan pada trauma reperfusi sebagai penyebab terjadi nya MVO.

Reperfusi aliran koroner diperlukan pada miokardium yang mengalami iskemia. Reperfusi memfasilitasi penyelamatan kardiomiosit dan menurunkan angka kesakitan dan kematian. Namun kebalikannya

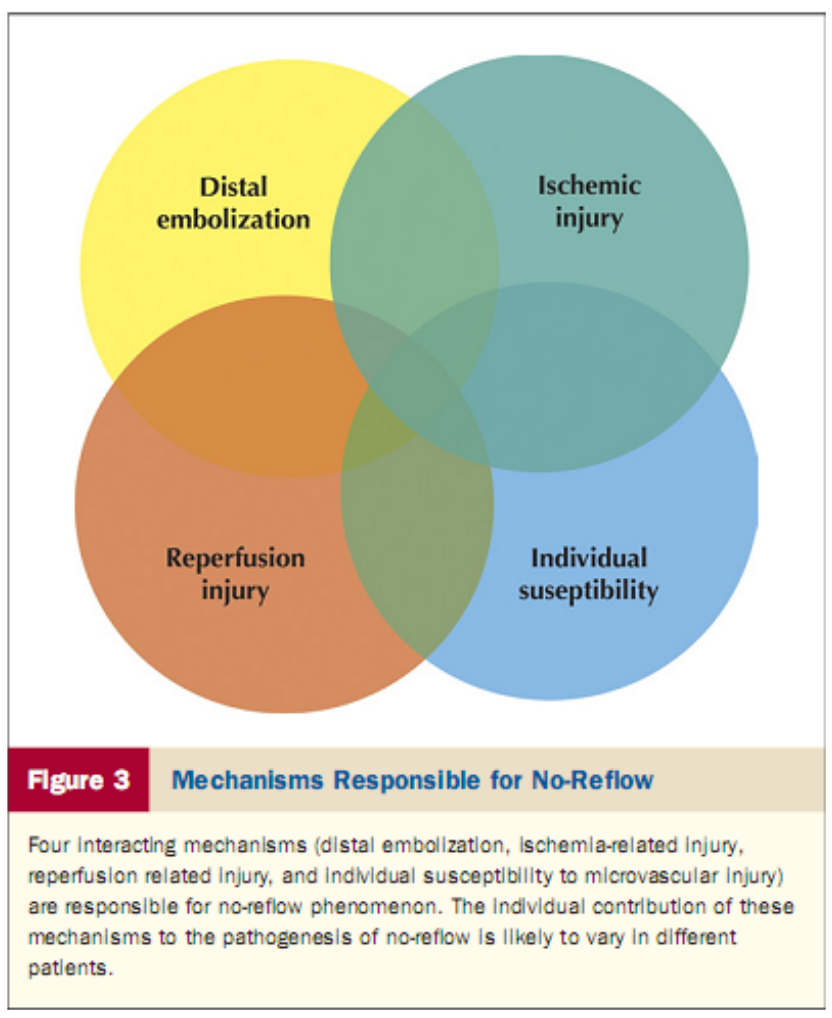

Gambar 1. Interaksi dari 4 komponen yang berperan dalam no reflow. ${ }^{3}$ reperfusi area yang mengalami iskemia dapat menimbulkan disfungsi miosit, yang disebut sebagai repefusion injury. Faktor yang menimbulkan reperfusi tidak hanya trombolisis, tetapi juga intervensi koroner perkutan dan coronary artery bypass grafting (CABG). Miokardium dapat mentoleransi hanya sampai dengan 15 menit iskemia miokardium yang berat dan total tanpa menimbulkan kematian kardiomiosit. ${ }^{7}$

\subsection{Mekanisme dan mediator reperfusion injury}

Beberapa mekanisme dan mediator reperfusion injury yang berperan antara lain oksigen radikal bebas, jumlah kalsium intraseluler yang berlebih, disfungsi mikrovaskular endotel dan perubahan metabolisme di miokardium dapat dilihat pada gambar 2 .

\subsubsection{Oksigen radikal bebas}

Produksi yang berlebihan dari reactive oxygen Species (ROS) adalah mekanisme yang penting pada reperfusion injury. Molekul oksigen ketika bertemu dengan miokardium yang mengalami iskemia, akan mengalami perubahan bertahap yang akan menimbulkan pembentukan oksigen radikal bebas. Oksigen radikal bebas ini seperti anion superoksida, hidroksi radikal dan peroksinitrit akan dibentuk dalam beberapa menit dari terjadinya kembali aliran atau reflow dan menjadi peran penting pada reperfusion injury. Oksigen radikal bebas juga dapat dihasilkan dari sumber lain seperti xanthineoxidase, cytochromeoxidase, cyclooxygenase, dan oksidasi dari katekolamin. Reperfusi juga merupakan stimulus yang poten terhadap aktivasi dan akumulasi netrofil yang juga akan berperan sebagai stimulus dalam pembentukan ROS.

Radikal bebas akan merangsang endotel mengeluarkan faktor aktivasi platelet yang akan menarik netrofil dan meningkatkan produksi oksidan radikal dan derajat reperfusion injury. ROS juga akan menetralisir nitric oxide, mempercepat disfungsi mikrovaskular dan trauma endotel. ${ }^{7}$

\subsubsection{Disfungsi endotel dan trauma mikrovaskular}

Reperfusi mengakibatkan disfungsi endotel dan trauma mikrovaskular yang bermakna. Terjadi peningkatan produksi vasokonstriktor yang poten, 


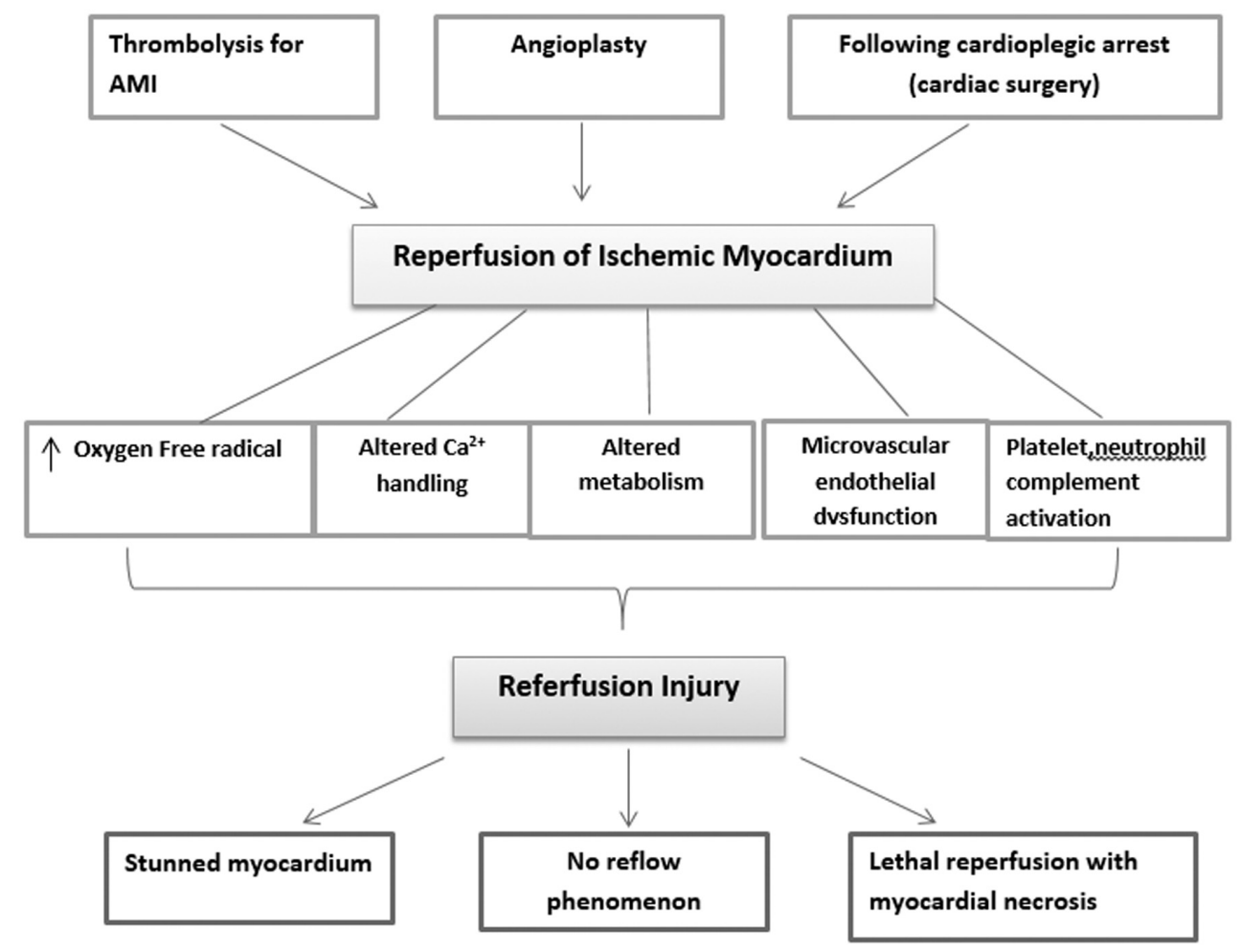

Gambar 2. Mekanisme dan mediator yang berperan dalam reperfusion injury. ${ }^{7}$

seperti endotelin 1 dan ROS yang akan meningkatkan vasokonstriksi koroner sehingga menurunkan aliran darah. Selanjutnya disfungsi endotel akan memfasilitasi ekspresi dari fenotip protrombotik yang ditandai dengan aktivasi netrofil dan platelet, yang merupakan mediator penting pada reperfusion injury. ${ }^{8}$

\subsubsection{Perubahan Calcium Handling}

Perubahan keseimbangan kalsium intraseluler berperan penting dalam terjadinya reperfusion injury. Iskemia dan reperfusion akan meningkatkan kalsium intraseluler, efek ini berkaitan dengan peningkatan sarcolemmal calcium entry melalui L-type calcium channel atau merupakan akibat sekunder dari perubahan sarcoplasmic reticulum calcium cycling. Akibat kalsium dalam jumlah banyak di intrasel akan mengganggu sensitivitas miofilamen terhadap kalsium. Aktivasi dari kalsium dependent protease (calpain I) sehingga terjadi proteolisis miofibril. ${ }^{7}$

\subsubsection{Perubahan metabolisme miokardium}

ROS dapat merangsang peroksidasi lipid mikrosomal dan sel membran, dengan kerusakan sel membran dan fungsi retikulum sarkoplasma termasuk inaktivasi pompa ATPase. Terjadinya kalsium berlebihan intraseluler, akan dikomunikasikan dengan sel yang berdekatan yang akan merangsang nekrosis jalur kontraksi. ${ }^{9}$

\subsubsection{Aktivasi netrofil}

Netrofil adalah komponen inflamasi yang dominan dalam injury setelah iskemia. Gambar 3. Iskemia reperfusi mempercepat pengeluaran ROS, sitokin dan mediator proinflamasi yang mengaktivasi netrofil dan endotel pembuluh darah koroner. Aktivasi sel ini akan meningkatkan ekspresi molekul adesi netrofil dan endotel, yang akan merekrut netrofil ke permukaan endotel dan memulai kaskade interaksi sel-sel spesifik, diawali dengan perlekatan netrofil ke endotel pembuluh darah, diikuti migrasi transendotel yang akan berinteraksi langsung dengan miosit. ROS akan merangsang peroksidasi lipid dari membran sel ( seperti polimorfonuklear, platelet) dan pengeluaran leukotriene B4 dan tromboksan A2 yang menyebabkan agregasi platelet, aktivasi netrofil dan netrofil plug. 


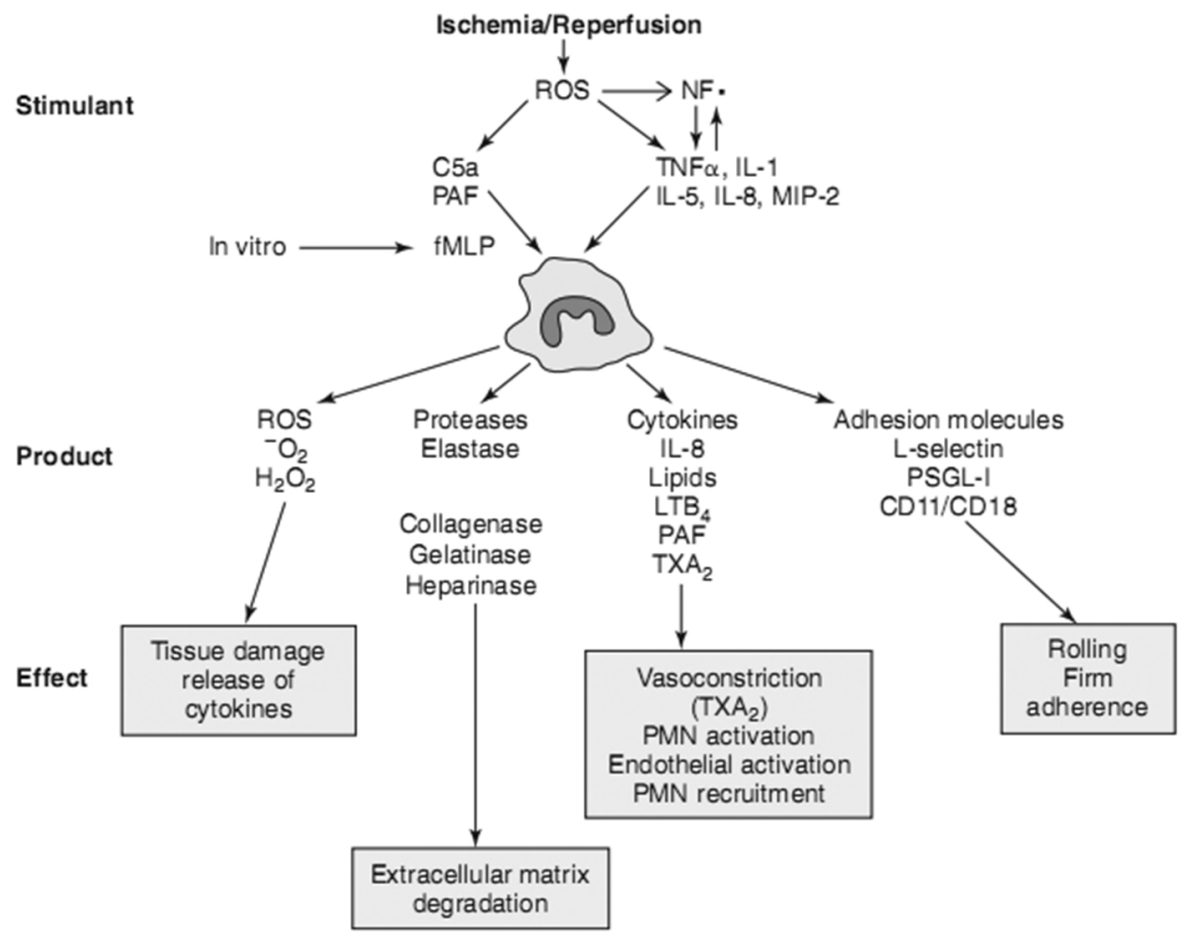

Gambar 3. Peranan aktivasi netrofil, produk turunan dari netrofil yang berperan pada iskemia reperfusi miokardium. ROS dihasilkan oleh netrofil atau sel endotel koroner yang merangsang pengeluaran faktor proinflamasi pada miokardium yang mengalami iskemia reperfusi, seperti peningkatan transkripsi faktor melalui NF-nB. Faktor - faktor ini kemudian akan mengaktifkan netrofil untuk menghasilkan ROS, protease, berbagai sitokin dan mediator lipid dan meningkatkan ekspresi molekul adesi yang berinteraksi dengan endotel dan kardiomiosit. ${ }^{10}$

Aktivasi netrofil akan mempercepat reperfusion Injury yaitu netrofil melekat ke endotelium menyebabkan kapiler plug pada miokardium yang mengalami infark, netrofil meghasilkan radikal bebas dan oksida stress seperti superoksida dan hidroksi radikal yang secara langsung menciderai endotel, deaktivasi endothelial derived relaxing factor (EDRF) dan merubah tonus pembuluh darah, sel polimorfonuklear mengeluarkan ROS, enzim proteolitik dan produk lipooksigenase seperti enzim lisosomal proteolitik dan mieloperoksidase yang mempengaruhi fungsi platelet dan endotel. ${ }^{9}$

Target terapi farmakologi meliputi berbagai komponen, target yang efektif antara lain menghambat pengeluran atau akumulasi dari mediator proinflamasi, mengubah aktivasi endotel dan netrofil, mengurangi perlekatan molekul ekspresi di endotelium, netrofil dan miosit. ${ }^{8}$

\subsection{Peranan trimetazidine pada reperfusion injury}

Trimetazidine (TMZ;1-[2,3,4-trimethoxybenzyl] piperazine) adalah agen anti iskemia yang secara selektif menghambat aktivitas akhir dari enzim jalur oksidasi asam lemak 3-ketoacyl coenzyme Athiolase. ${ }^{11,12}$ Proses transport asam lemak kedalam mitokondria dan beta oksidasi dapat dilihat dari gambar $4 .{ }^{12}$

Asam lemak di transport ke sitoplasma dan mengaktivasi CoA esters. Acyl CoA memasuki mitokondria sebagai fatty acyl carnitine melalui sistem enzim ((carnitine palmitoyl transferase I [CPTI] ,carnitine acyl- -arnitine translocase[CAT], carnitine palmitoyl transferase II [CPTII]) The intra mitochondrial acyl CoA then enters $\beta$-oxidation spiral, dimana proses terakhir adalah 3-keto acyl CoA thiolase (3-KAT). Enzim ini di inhibisi oleh trimetazidine. 


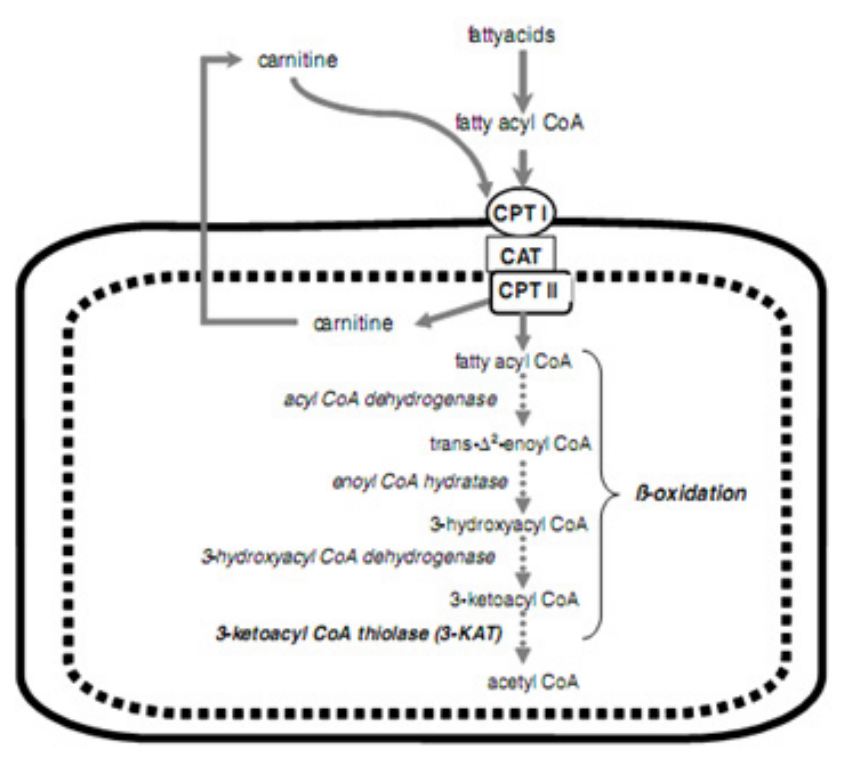

Gambar 4. Proses transport asam lemak ke dalam mitokondria dan beta oksidasi. ${ }^{12}$

Inhibisi 3-KAT mengakibatkan penurunan oksidasi asam lemak mitokondria. Seiring produksi energi asam lemak di batasi, substrat seperti glukosa akan digunakan sebagai sumber energi. ${ }^{11}$ Pemberian obat ini membantu merubah subtrat energi, menghasilkan inhibisi oksidasi asam lemak dan meningkatkan oksidasi glukosa. Studi klinis menunjukkan TMZ memiliki efek kardioprotektif pada pasien dengan iskemia miokardium termasuk infark miokardium. ${ }^{12}$ Trimetazidine efektif sebagai antiangina tetapi tidak memiliki efek inotropik negative atau vasodilator. ${ }^{13}$

Anti angina yang baik adalah yang memiliki kemampuan menghilangkan iskemia, dan karena itu tidak memiliki kemampuan untuk menimbulkan preconditioning. Ini konsep yang penting karena trimetazidine suatu antiangina dan bukan preconditioning. Preconditioning merupakan respon dari iskemia, sehingga menimbulkan kondisi fosforilase oksidatif yang tidak lengkap. Berbeda dengan proteksi mitokondria sebagai anti iskemia yang dapat berperan sebagai 'mitochondrial coupling agent' (gambar 5), pada gambar terlihat trimetazidine dapat menghambat kemampuan preconditionng dalam mengiduksi efek iskemia. Konsep ini sesuai dengan kemmapuan trimetazidie dalam menghambat oksidasi asam lemak, karena konsentrasi tinggi asam lemak menimbulkan efek uncoupling mitokondria. ${ }^{14}$

Trimetazidine berperan dalam mengurangi kejadian MVO dengan cara mempengaruhi akumulasi

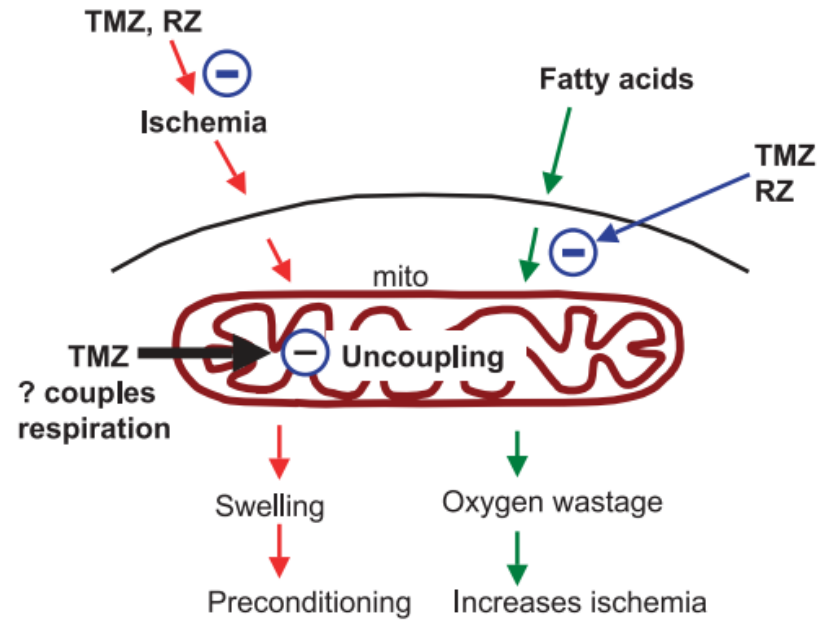

Gambar 5. Dua konsekuensi mitokonria uncoupling. Sisi kiri iskemia melalui jalur uncoupling meningkatkan preconditioning. Sisi kanan asam lemak melalui jalur uncoupling menggunakan oksigen sehingga menimbulkan iskemia. ${ }^{14}$

netrofil, dinilai dari penelitian yang dilakukan Wiliam dkk pada tahun 1993, dari 25 kelinci yang mengalami oklusi arteri koroner selama 30 menit dan setelah 3 jam mengalami reperfusi area at risk dari miokardium dinilai menggunkan kontras, 12 kelinci menerima 2,5 $\mathrm{mg} / \mathrm{kg}$ trimetazidine IV, 13 kelinci sebagai kontrol, didapatkan akumulasi netrofil yang bermakna pada area at risk kelompok kontrol, sedangkan pada kelompok trimetazidine jumlah nya sangat menurun. ${ }^{15}$ Dengan demikian luas infark akan menurun dan risiko kerusakan miokard akan lebih kecil, sebagaimana penelitian yang dilakukan oleh Belcher dkk, meneliti pengaruh trimetazidine pada luasnya infark, pada kelinci yang mengalami oklusi koroner selama 45 menit kemudian reperfusi setelah 24 jam. Kelompok penelitian nya adalah 7 kelinci sebagai kontrol dan 7 kelinci mendapat terapi trimetazidine $3 \mathrm{mg} / \mathrm{kg}$ sebelum perlakuan. Kemudian diukur luasnya infark didapatkan penurunan yang bermakna luasnya infark pada kelompok yang diberikan trimetazidine, disimpulkan bahwa pemberian trimetazidine sebelum terjadinya infark efektif menurunkan luasnya infark. ${ }^{16}$

Untuk menilai efektifitas dari terapi reperfusi yang kita berikan pada pasien dengan infark miokardium akut dapat dinilai dari jumlah miokardium yang diselamatkan dengan mengukur luas area infark. Penyelamatan miokardium adalah hal yang prinsip pada pasien yang diberikan terapi reperfusi. ${ }^{17}$ Khaled dkk meneliti efek trimetazidine 
dalam memperbaiki reperfusi pada pasien IMA EST yang menjalani IKPP dengan menilai myocardial salvage index, dari 44 pasien, 22 pasien diberikan trimetazidine $70 \mathrm{mg}$ sebelum IKPP dilanjutkan sampai dengan dilakukan pemeriksaan SPECT, 22 pasien sebagai placebo, didapatkan bahwa trimetazidine memperbaiki myocardial salvage index pada pasien dengan TIMI 3 flow paska tindakan dibanding kan dengan pasien TIMI 2 flow, dengan hasil pada kelompok yang menerima trimetazidine sebelum IKPP didapatkan myocardial salvage index $(38.32 \pm 26.6 \%$ vs. $16.80 \pm 13.88 \%)$ dan kelompok yang tidak diberikan trimetazidine sebelum IKPP $(28.09 \pm 27.95 \%$ vs. $15.99 \pm 13.44 \%)$. Tabel $1 .{ }^{18}$ and Left Ventricular Remodeling in Reperfused Anterior Wall Myocardial Infarction. Circulation 1996;93:223-8.

6. Ronen Jaffe TC, Geoffrey Puley,Alexander Dick,Bradley H. Strauss. Microvascular Obstruction and the No - Reflow Phenomenon After Percutaneous Coronary Intervention. Circulation 2008;117:3152-6.

7. Subodh Verma PWMF, Richard D Weisel, Jagdish Butany, Vivek Rao, Andrew Maitland, et al. Fundamentals of Reperfusion Injury for the Clinical Cardiologist. Circulation 2002;105:2332-6.

8. James E. Jordan Z-QZ, Jakob Vinten-Johansen. The role of neutrophils in myocardial ischemia - reperfusion injury. Cardiovascular Research 1999;43:860-78.

9. Sheng Kang YY. Coronary microvascular reperfusion injury

Tabel 1. Perbandingan antara initial perfusion defect, final infarction size dan myocardial salvage index pada kedua kelompok pasien dengan TIMI 3 flow. ${ }^{18}$

\begin{tabular}{lccc}
\hline & Group 1 & Group 2 & $P$ value \\
\hline $\begin{array}{l}\text { Initial perfusion defect } \\
\text { Mean } \pm \text { SD }\end{array}$ & $28.5 \pm 12.2$ & $25.11 \pm 15.4$ & $P=$ NS \\
$\begin{array}{l}\text { Final infarction size } \\
\text { Mean } \pm \text { SD }\end{array}$ & $16.25 \pm 9.6$ & $17.44 \pm 11.5$ & \\
$\begin{array}{l}\text { Salvage index } \\
\text { Mean } \pm \text { SD }\end{array}$ & $38.32 \pm 26.6$ & $28.09 \pm 27.9$ & \\
\hline
\end{tabular}

\section{Daftar Pustaka}

1. Gabriel Steg SKJ, Dan Atar, Luigi P. Badano, CarinaBlo “mstrom-Lundqvist, Michael A. Borger. ESC Guidelines for the management of acute myocardial infarction in patients presenting with ST-segment elevation. European Heart Journal 2012;33:2569-619.

2. Lori Mandelzweig AB, Valentina Boyko,Hector Bueno,Nicolas Danchin, Gerasimos Filippatos, et al. The second Euro Heart Survey on acute coronary syndromes : characteristics, treatment, and outcome of patients with ACS in Europe and the Mediterranean Basinin 2004. European Heart Journal 2006.

3. Giampaolo Niccoli FB, Leonarda Galiuto,Filippo Crea. Myocardial No-Reflow in Humans. Journal American College of Cardiology 2009;54:281-92.

4. Hiroshi Ito TT, Noriko Sakai,Hisahiro Yu, Yorihiko Higashino, Kenshi Fujii. Lack of Myocardial Perfusion Immediately After Successful Thrombolysis A Predictor of Poor Recovery of Left Ventricular Function in Anterior Myocardial Infarction. Circulation 1992;85:1699-705.

5. Hiroshi Ito AM, Katsuomi Iwakura,Shin Takiuchi,Tohru Masuyama, Masatsugu Hori, et al. Clinical Implications of the 'No Reflow' Phenomenon A Predictor of Complications and no-reflow in acute myocardial infarction. Clin Invest Med 2007;30(3): E133-E45.

10. Vinten-Johansen J. Involvement of neutrophils in the pathogenesis of lethal myocardial reperfusion injury. Cardiovascular Research 2004;61:481-97.

11. Onay-Besikci A, Ozkan SA. Trimetazidine revisited: a comprehensive review of the pharmacological effects and analytical techniques for the determination of trimetazidine. Cardiovasc Ther 2008;26:147-65.

12. Group TE-F. Effect of 48-h intravenous trimetazidine on shortand long-term outcomes of patients with acute myocardial infarction,with and without thrombolytic therapy. European Heart Journal 2000;21:1537-46.

13. Paul F. Kantor AL, Raymond Kozak, Gary D. Lopaschuk. The Antianginal Drug Trimetazidine Shifts Cardiac Energy Metabolism From Fatty Acid Oxidation to Glucose Oxidation by Inhibiting Mitochondrial Long-Chain 3-Ketoacyl Coenzyme A Thiolase. Circulation Research 2000;86:580-8.

14. Opie LH. Preconditioning and metabolic anti-ischaemic agents. European Heart Journal 2003;24:1854-6.

15. F.M Williams KT, M.Kus, T.J Wiliam. Trimetazidine inhibits neutrophil accumulation after myocardial ischemia and reperfusion in rabbits. Journal of Cardiovascular pharmacology 


\section{Mehi T dkk: Peranan Trimetazidine pada Reperfusion injury}

$1993 ; 22: 828-33$.

16. Belcher PR, Drake-Holland AJ, Hynd JW, Noble MI. Effects of trimetazidine on in vivo coronary arterial platelet thrombosis. Cardiovasc Drugs Ther 1993;7:149-57.

17. Ingo Eitel SD, Georg Fuernau, Lysann Hildebrand, Matthias Gutberlet, Gerhard Schuler,et al. Prognostic Significance and Determinants of Myocardial Salvage Assessed by
Cardiovascular Magnetic Resonance in Acute Reperfused Myocardial Infarction. Journal American of Cardiologi 2010;55:2470-9.

18. Foad Khaled EA, Bastawy Islam,Khaled Saeed. Effect of trimetazidine on myocardial salvage index in patients with acute ST segment elevation myocardial infarction undergoing primary PCI. The Egyptian Heart Journal 2013;65:181-9. 